
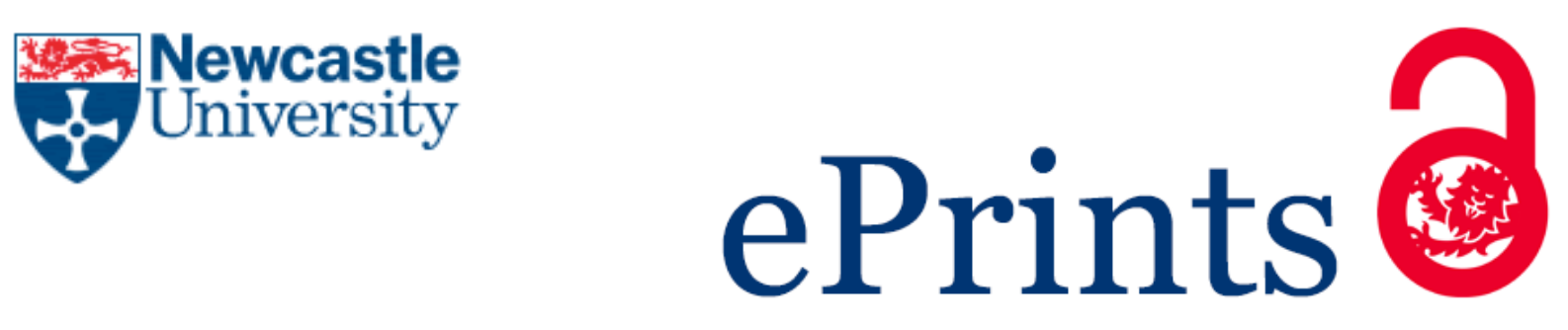

Wang $X$, Vallance $P$.

The engagement of higher education in regional development in China. Environment and Planning C: Government and Policy 2015, 33(6), 1657-1678.

\title{
Copyright:
}

This is the authors' accepted manuscript of an article that has been published in its final definitive form by Sage Publications Ltd, 2015.

DOI link to article:

http://dx.doi.org/10.1177/0263774X15614143

Date deposited:

$06 / 01 / 2016$

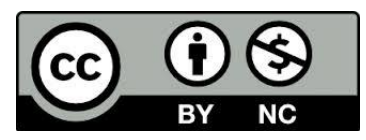

This work is licensed under a Creative Commons Attribution-NonCommercial 3.0 Unported License 


\section{The engagement of higher education in regional development in China}

Xuefeng Wang

Centre for Urban and Regional Development Studies (CURDS), Newcastle University, Newcastle upon Tyne, NE1 7RU, the United Kingdom; e-mail: xuefeng.wang@ncl.ac.uk Paul Vallance

Centre for Urban and Regional Development Studies (CURDS), Newcastle University, Newcastle upon Tyne, NE1 7RU, the United Kingdom; e-mail: paul.vallance@ncl.ac.uk

Please cite full published version: Wang, X. and Vallance, P. (2015) The engagement of higher education in regional development in China, Environment and Planning $C$ : Government and Policy 33, (6), 1657-1678. 
The engagement of higher education in regional development in China

\begin{abstract}
The widely established role of higher education institutions (HEIs) in contributing to regional development is now also encouraged by the Chinese government. This development has been enabled by changes in state policy that in some respects align with global trends towards expansion, marketisation, and regional decentralisation in national higher education systems. However, the regional engagement of HEIs in China takes distinctive forms that are shaped by specific features of its governance system, including the politicisation of higher education, the incorporation of HEIs into the administrative hierarchy, and the disequilibrium of funding schemes between central and provincial owned HEIs. This paper provides a preliminary analysis of this relationship between higher education and regional development in China. It argues that the policy to encourage regional engagement by HEIs in China has generally served to enhance patterns of regional inequality between the coastal and inland regions and between upper and lower-administrative level cities.
\end{abstract}

Keywords Higher education, regional engagement, regional development, China

Acknowledgements We are grateful for the helpful comments of two anonymous referees and the editor. We would also like to thank John Tomaney and John Goddard for their very useful feedback on earlier versions of this paper. 


\section{Introduction}

The last three decades have seen the emergence of a globalised knowledge economy and fast economic growth in China which has, by contrast, been driven largely by labour-intensive manufacturing based industrialisation. While this may be described by the theory of global production networks (GPNs) as necessary for development from a transnational perspective (Coe et al., 2004; Ernst and Kim, 2002; Henderson et al., 2001), little attention has been paid to the significant increase of subnational regional disparity and inequality it may cause in peripheral regions at the low end of GPNs, especially in large countries such as China (Fujita and $\mathrm{Hu}$, 2001; Zhang and Zhang, 2003). Indeed, regional disparity and inequality have become a major social, political, and economic concern in China in spite of the overall fast economic growth in the country (Fan, 1997; Fan and Sun, 2008; Lu et al., 2007; Shen, 2004). In order to tackle these issues, the Chinese government has made extensive efforts to encourage and support higher education to play a more important role both in industrial upgrading and regional development (MOE, 2006; MOE et al., 1992; MOST and MOE, 2000). However, whether the policy is conducive to the overall objectives of rebalancing regional development or not is open for debate.

On an international level, the notion that higher education institutions (HEIs) can be central agents in knowledge-based regional development has become widely recognised in both academic and policy discourse. A wide-ranging literature has developed that explores different facets of this relationship; including the 'multiplier' impacts of HEI employment and expenditure in the local economy, the migration patterns of graduates entering regional labour markets, the production of localised knowledge 'spillovers' through academic research, the effect on university-firm links of science and technology park developments, and the role of universities in regional innovation systems (for reviews see Goddard and Vallance, 2013; 
Lawton Smith, 2007; Uyarra, 2010). This literature has also emphasised how these different forms of engagement are shaped by the wider institutional contexts in which the HEIs are based, which vary between countries and regions with different governance arrangements and socio-economic conditions. These contexts are configured through the complex interplay of policy drivers and barriers from the spheres of both higher education and regional economic development (OECD, 2007).

This paper will aim to extend this predominately western-focused literature by exploring the different forms and effects of regional engagement by HEIs in China. Since the mid-twentieth century the Chinese higher education system has experienced a large expansion and undergone several significant restructurings to align with changes in national development policy, notable amongst which are nationalisation during the centrally planned economy, and marketisation and regionalisation in the post reform period. While the changes of the higher education system have been covered in previous work (e.g. Liu, 2007; Min, 2004; Mok, 2000; Mok and Wat, 1998; Williams et al., 1997), and a parallel literature exists on corresponding changes to regional policy in China (e.g. Fan, 1997; Li and $\mathrm{Wu}, 2012$ ), the connections between these two processes have not been the main focus of previous studies. The paper will elucidate this relationship between higher education and regional development in China by, at the same time, considering it in light of the international literature on the subject, and situating it in the specific context of the Chinese economic and governance system.

The paper has five further sections. Section 2 reviews the international literature on the role of the state in shaping the contribution of HEIs to regional development, structured around three common processes of change in national higher education systems: expansion, marketisation, and regional decentralisation. Section 3 briefly traces the historical development of Chinese higher education over the last six decades, concentrating on periods 
of significant restructuring during the $1950 \mathrm{~s}$, the post-Mao economic reforms of the $1980 \mathrm{~s}$, and the subsequent move towards a more western-style partly decentralised and partly marketised system during the 1990s and 2000s. Section 4 discusses the political and administrative framework in which Chinese HEIs are positioned in more detail and how this shapes their relationship with governments at different levels. Section 5 builds on the analysis of the previous two sections to discuss the Chinese character of common forms of regional engagement by HEIs, including providing high-skilled workers to local labour markets, university enterprises and links with industry, and science park or campus development projects. Section 6 outlines the key conclusions from the paper.

\section{Higher education, the state, and regional development}

A strand of the considerable literature on the contributions that HEIs make to regional development has focused on exploring how these are shaped by state higher education and related economic development policies. This review section focus on three common forms of change in higher education systems internationally - national expansion, marketisation, and regional decentralisation - highlighting how they can feed into wider processes of (often uneven) regional development. This forms a background to the analysis of the Chinese case in the remainder of the paper.

\subsection{National Development}

The contribution of HEIs to regional development is framed in the first place by the national higher education policies of central governments. During the twentieth century universities increasingly became part of state-regulated national higher education systems (Delanty, 2002). After the second world war, these systems underwent an international trend for 
significant expansion towards 'mass' participation, driven in-part by national social and economic development concerns to extend higher education access to different segments of the population and increase human capital in labour markets (Schofer and Meyer, 2005). In many cases this expansion led to the higher education sector having a more comprehensive geographical coverage through the establishment of new universities or colleges in parts of the country previously without a HEI (Teixeira et al., 2014) ${ }^{1}$. However, the regional benefits arising from this expansion process may ultimately still have proved uneven: international evidence has indicated that in countries with open labour markets, a large proportion of students migrate to core regions upon graduation where prospective career opportunities are greater (Hoare and Corver, 2010; Kodrzycki, 2001; Venhorst, 2013). These migration patterns can particularly favour larger cities and serve to reproduce urban hierarchies (Benneworth and Herbst, 2015).

During the same post-war period, the instrumental value of the research function performed by universities also came to be recognised in national economic development strategies. An initial focus on science and technology policies to increase national research and development capability has, in more advanced economies, shifted towards innovation policies that attempt to engender inter-relationships between the different types of public and private organisations that generate and apply knowledge in national systems (Lundvall and Borrás, 2005). These national science and innovation policies can also have uneven regional effects, especially when increased investment in public scientific and $R \& D$ resources are concentrated in certain parts of the country. In some cases, where government innovation policy does not have a strong explicit regional dimension, this may be a by-product of pursuing overall national research excellence. For instance in the United Kingdom the policy of directing the majority of research funding into the highest performing institutions has continued to reproduce the favoured position of select leading universities located in London, 
Oxford, and Cambridge in the greater south east of England (Goddard and Vallance, 2013). In other cases, however, this geographic concentration of public research and development capabilities may be part of a deliberate economic development strategy, especially in industrialising countries in which state-driven efforts to stimulate growth have been focused on certain regions or urban centres (Schiller, 2006; Sohn et al., 2009).

This investment in academic research capability will have wider knock-on effects in the economy through mechanisms of knowledge spillover between universities and industry including collaborative research, spin-off firms, and movement of staff (Breschi and Lissoni, 2001). The importance of spatial proximity in the networks that enable this knowledge spillover means that the resulting collective learning benefits are likely to be localised (Lawton Smith, 2007). In regions with strong entrepreneurship-supporting economies, this form of knowledge externality may help support the growth of clusters in science or technology-based industries (Patton and Kenney, 2010).

\subsection{Marketisation}

The expansion of higher education sectors discussed above has, due to the greater demands on public funding, often been accompanied by marketisation reforms. This is most often discussed in relation to a shifting from state grants to student tuition fees as the main means of funding teaching activity, but can also refer to connected or parallel changes increasing competition in, for example, systems for allocating research resources (Dill, 1997). Marketisation is also potentially related closely to trends for more provision of higher education by private institutions and/or funding of research from industry rather than government sources (Teixeira, 2014). These reforms have the effect of reinforcing hierarchical distinctions in national and global higher education sectors between researchintensive universities with global standing and more teaching focused universities or colleges 
(Marginson, 2006). In turn these different institutional types assume varying roles in regional development: leading universities may be less embedded in their regional economy than teaching-focused institutions with an orientation towards vocational training of local students, but do have the potential to generate wider innovation impacts through their research and commercialisation activities (Boucher et al., 2003; Huggins and Johnston, 2009). For research-intensive institutions in particular, the prioritisation of academic 'excellence' over social 'accessibility' can act as a barrier to regional engagement (see Tomaney and Wray, 2011).

As well as increased competition over scarce government resources for traditional academic functions, the pressure on public funding is widely believed to have contributed to universities throughout the world becoming more 'entrepreneurial' in seeking new revenue streams (Clark, 1998). Slaughter and Leslie (1997; 2001) argue that what they describe as an international trend towards 'academic capitalism' involves both market-like and market behaviours. Where market-like behaviours are focused on activities by institutions or faculty that involve "competition for funds from external resource providers" such as research councils or fee-paying students to undertake academic research or teaching, fully market behaviours "refer to for-profit activity on the part of institutions, activity such as patenting and subsequent royalty and licensing agreements, spin-off companies, arms-length corporations ... and university-industry partnerships when these have a profit component" (Slaughter and Leslie, 2001, p.154). As mentioned above, such directly entrepreneurial activity that involves industry links or the commercialisation of research has been emphasised in regional economic development discourse as a key mechanism of knowledge spillover that can feed into local innovation and cluster formation processes (Etzkowitz, 2012). Less discussed, but still notable in terms of its impact on urban and regional development, are entrepreneurial university activities in the sphere of property and real estate development, 
that can include the construction of new university buildings or campuses, or involvement in projects like science parks (Goddard and Vallance, 2013; Perry and Wiewel, 2008; van Winden et al., 2012). In the introduction to an edited book of international case studies on this subject, Perry and Wiewel (2008) emphasise the role of state policy in mediating the land development activities of universities in cities by creating demand for new facilities through expansions in higher education sectors, as well as determining the funding and planning regulation frameworks in which development occurs.

\subsection{Regional decentralisation}

While in many countries higher education policy remains the preserve of central governments, reflecting the national development role discussed above, in other cases there is a significant level of regional decentralisation in the system. The clearest-cut examples of higher education being governed at a sub-national level are in large countries with federal systems of government such as the USA, Canada, and Germany. The higher education systems of these federal states vary considerably from country to country, but are all characterised by a complex multi-level system where different aspects of higher education are funded and regulated by federal and regional or provincial state governments (Cameron, 1992) ${ }^{2}$. The growth of political devolution movements over the past twenty years, driven by a combination of cultural, governance and economic factors (see Keating, 1997; RodríguezPose and Gill, 2003; Rodríguez-Pose and Sandall, 2008), have created a dynamic towards regionalisation in other higher education systems. In European countries such as Belgium, the United Kingdom, and Spain in particular, higher education has been amongst the first areas of state powers decentralised to new or strengthened regional governments (Paterson, 2001).

Regional or provincial state governance can lead to significant differentiation of higher education systems within a country. For instance, the USA has marked diversity in public 
funding of universities between state governments (Trow, 1992). This varies the ability of universities to set tuition fees at levels that attract prospective students (from either inside or outside the state), which in turn subsequently impacts on graduate numbers in local labour markets (Cooke and Boyle, 2011; Groen and White, 2004). In the United Kingdom, the relatively short period since devolution in the late 1990s has seen considerable divergence of higher education policies (particularly relating to tuition fees) between the Westminster government (covering England) and devolved administrations in Wales, Northern Ireland and especially Scotland (Keating, 2005).

In most countries, regardless of system of government, the funding of university research is controlled from the centre, in-part because this is an important instrument of national public policy in a number of areas (including economic development) (Cameron, 1992). In some unitary as well as federal states, however, the establishment of economic development and governance institutions at a regional level (Danson and Lloyd, 2012; Jones, 2001) has led to a degree of re-scaling of science and innovation polices from complete centralisation towards multi-level systems (Crespy et al., 2007; Goddard and Chatterton, 1999; Kitagawa, 2005). This may rarely extend to direct funding of core academic research by sub-national governments, but the incorporation of universities as central actors in sub-national economic development strategies has facilitated their integration into regional innovation systems. However, this extra institutional capacity is often constrained by the limited resources that regions are allocated by central governments and the extent to which the policy frameworks they operate in are defined at the national level (Perry and May, 2007).

This section has outlined how common types of regional engagement by HEIs - including those related to training future graduate workers, supporting innovation through research commercialisation and industry links, developing science parks, and participating in building projects with urban development impacts - have been shaped by developments towards 
expansion (including growing investment in research), marketisation, and regional decentralisation in national higher education systems. These general trends and their effects, which vary in form and degree from country to country, have been outlined by drawing on a literature that is predominately focused on Europe, North America, and Australia. The next section describes the evolving trajectory of higher education policy in China since the midtwentieth century, in order to begin to explore how comparable processes have unfolded in this specific non-western setting.

\section{Higher education policy in China}

The Chinese national higher education system underwent a number of radical transformations of model and administrative accountability as a consequence of changes of government in the first half of twentieth century and changes of policy in the second half (Cai, 2006). Throughout these frequent transformations, China's higher education policy has been part of the core strategies of national development, but has only developed a regional development mission since the economic reform in the 1980s. This section will outline these changes.

The main foundations of the contemporary Chinese higher education system were laid by the Kuomintang government in the first half of the twentieth century. When the Chinese Communist Party (CCP) came into power in 1949, the government followed the former Soviet model of higher education, prioritising the development of polytechnics whilst discouraging universities ( $\mathrm{Li}$ et al., 2003). All HEIs were nationalised and then reconstituted into new universities, polytechnics, colleges, and vocational schools in 1952 (Min, 2004). The restructured HEIs were affiliated with the central government ministries of related industries and relocated to different cities throughout the country (Zhou, 2006). New polytechnics, colleges, and vocational schools were founded in the same way in the following 
decades (Zhang, 2009). The research function was moved from HEIs to a separate national research system led by the Chinese Academy of Science (CAS) and the Chinese Academy of Social Science (CASS), so that up until the 1990s, apart from a few universities, HEIs in China were teaching-only institutions (Liu, 2007).

One of the most distinctive features of the higher education under the government of the CCP is that HEIs have been integrated into the communist political and administrative hierarchy (Yang, 2010), which itself is structured as (in descending order) national, ministerial/provincial, prefectural, county, and township levels of administration. Every public funded HEI has been assigned to a specific level of administration, which could be as high as equivalent to the vice-ministerial level or as low as the county level depending on their perceived importance (Figure 1). The higher the administrative level of a HEI the more power it has to make managing decisions and the more funding it receives from the government. For instance, the vice-ministerial level universities report directly to the State Council and enjoy vice-ministerial level autonomous power of administration, whereas prefectural and vice-prefectural level HEIs report to the responsible central ministries or provincial-level governments, and have less power of administrative autonomy (Wang, 2010). In the post-reform period, this classification is usually connected with the research capability of a given HEI.

\section{Insert Figure 1 here}

Such nationalisation and politicisation of HEIs paved the way for higher education to become oriented towards serving the needs of national development, with no regional dimensions taken into account (Chen and $\mathrm{Wu}, 2012$; Cheng, 1998). All graduates were assigned to jobs at central government owned enterprises and/or research institutions, which themselves also did not have strong connections with the localities where they were located ${ }^{3}$ (Zhou, 2006). It was 
only with the decentralisation policy announced in 1985 that genuine links between higher education and local and regional development became possible, even though the main aim of this decentralisation was to encourage local governments, individuals, and other non-state bodies, subject to the CCP's policies, to become involved in the provision of higher education (Wei and Zhang, 1995). The decentralisation involved a number of related policies, notable amongst which were marketisation and regionalisation.

The marketisation of higher education in China took two forms. The first was to allow private individuals and enterprises to establish HEIs in the form of self-sufficient enterprises, in response to the pressing demand for high-skilled workers from the booming private sector (MOE, 1993a). Privately funded and managed HEIs have subsequently emerged and quickly grown to become an indispensable provider of higher education in China. The number of privately funded HEIs had reached 1007 in 2011 with 7.73 million students (MOE, 2012) although they remain teaching-only institutions targeted at local labour markets. The second was the introduction of a type of what Slaughter and Leslie (1997; 2001) call academic capitalism, in which public HEIs are encouraged to recruit extra self-funded students on top of the national quotas, acquire non-state funding resources, and run arms-length enterprises and university-industrial joint ventures. This, together with the introduction of a "fees paying" policy in 1995/96 (Mok, 2000), had by 2009 led to public funding dropping to less than $40 \%$ of total higher education income nationally and to below $20 \%$ in some poor provinces (Shao and Wang, 2010).

Regionalisation ${ }^{4}$ involved the transfer of HEIs affiliated with the central ministries to provincial governments and the encouragement of local governments to establish locallyowned HEIs (Cheng, 1998). However, in contrast to the equivalent regional decentralisation process in most Western contexts, policy making is exclusively controlled by the Chinese 
central government leaving provincial governments only to bear the cost. From 1994 to 2007, 293 HEIs were transferred to provincial governments in this way (NBSC, 2008). By 2011, the number of fully provincial funded HEIs reached 1602, whilst the number of central government funded HEIs dropped to 111 (NBSC, 2012). Regionalisation has led to provincial governments becoming the predominant provider of higher education. Nevertheless, in the context of significant regional disparities between core cities and provinces in the coastal region and their counterparts in inland regions, regionalisation has resulted in a marked divergence in higher education funding between the rich and poor provinces. Ding and $\mathrm{Hu}$ (2012) and Shao and Wang (2010) estimate that funding (per student) received by HEIs in the core cities could be 7 times higher than that in poor provinces.

These decentralisation reforms have effectively mitigated the central government's "financial burden" in funding the rapid expansion of higher education (Mok, 2000) and allowed it to concentrate on funding nationally-leading universities that are capable of research excellence. The research function in universities was once again encouraged, with the Ministry of Education successively launching the so-called "211 Programme" to support 100 universities to become research-intensive universities at the turn of the $21^{\text {st }}$ century (MOE, 1993b) and the "985 Programme" to help nationally-leading universities develop toward becoming "world class" universities (Liu, 2007; Ma, 2004). Substantial extra funds were made exclusively available to the universities that qualified as part of these schemes. In order to meet the relevant criteria, some existing universities, polytechnics, and/or colleges were merged to become comprehensive universities (MOE, 1993b). Provincial governments were also asked to support the universities located in their region to bid for these designations (Ding, 2007). From 1993 to 2001, 708 HEIs had merged to become 302 universities, although the majority of the qualified universities were owned by the central government (MOE, 2009). 
Despite the relocation of some institutions in the centrally-planned economic period, HEIs are still unevenly distributed throughout China. This is particularly the case with the central government owned universities that are strongly committed to research. Table 1 lists the number of HEIs by province and accountability. While the eastern region has more HEIs in general, central government-owned universities are concentrated in a few core cities. Of the 110 central government-owned universities, 69 are located in the eastern region. More specifically, 46 out of the 112 "211 Universities" and 15 of the 39 "985 Universities" are

concentrated in just Beijing, Shanghai, and Jiangsu provinces (MOE, 2012). In the context of inequalities in the system of higher education funding, the concentration of central government-owned universities means that the more developed regions receive a greater share of financial support from the central government than poorer regions, even before the extra funding support for the " 211 " and " 985 " universities, which further enhances this trend, is taken into account.

\section{Insert table 1 here}

Although the Ministry of Education has designated a dozen "211 Universities" in the central and western regions in the last few years in response to this geographic imbalance, the level of funding support from the central government was much less than for universities designated in the first cohort. Moreover, because none of these universities belong to the central government, the responsible provincial governments were asked to provide match funding to the designated universities creating an added financial burden to these local governments.

In summary, this section has described changes in higher education policy in China that have allowed the system to evolve from one entirely focused on national development objectives to one in which, through decentralisation reforms, more direct links to local and regional 
development are also possible. These changes have involved elements of the expansion, marketisation, and regional decentralisation dynamics in national higher education systems that the preceding section identified as being important in encouraging and shaping the regional engagement effects of HEIs internationally. In China, however, HEIs remain positioned in the national political and administrative hierarchy that also fundamentally shapes their institutional characteristics, geographical location, and regional development impacts. The next section discusses the implications of this particular governance system in more detail.

\section{The politics of HEIs engaging in local and regional development}

The strong hierarchical administration and politicisation of both local and regional governance and HEIs complicate the relations between higher education and regional development in China in two major respects. First, there are five levels of government in China, each of which has its own relatively independent public finance (Dunford, 2011), which makes central-local relationships considerably more complex than in most equivalent western multi-level governance settings. Under the economic-centred development strategy, the prioritised functional responsibility of every unit of governments is to promote the economic growth of the place under its jurisdiction. Competition for resources therefore occurs not only between governments at the same level, but also between those at upper and lower levels (Man, 2011; Martinez-Vazquez and Qiao, 2011).

Second, because all public funded HEIs, state owned enterprises, non-government organisations, and even large private owned enterprises, are politicised and incorporated into the administrative hierarchy, the relations between HEIs and local and regional development depend greatly on the administrative levels ${ }^{5}$ in question. On the one hand, both the centrally 
owned and provincially owned HEIs have to fulfil the tasks mandated respectively by the central government and affiliated provincial governments, which means they must provide consultancy or other support to localities and regions for free. For example, HEIs are asked by their affiliated governments to send academic and administrative staff to prefectural or county level-governments to take secondment posts. On the other hand, unless attractive funding is offered, HEIs with higher level of administration will not voluntarily discuss official collaborations with local governments with a lower level of administration.

Nevertheless, spatial proximity often means that, despite these disparities in administrative level, close relationships are built between HEIs and the places where they are located. This has become more evident under the policy that local governments are asked to co-fund the universities located in their places but owned by the central government. In many cases, local political and government leaders take chair positions on various academic and non-academic boards in the universities. For example, the Secretary General of CCP at Chongqing has assumed the position of honorary chair on Chongqing University Board, a steering committee aiming to direct the development and fundraising policy, while a Deputy Mayor of the municipal government fulfils the role of chair ( $\mathrm{Li}$ and Zhao, 2009). Similar arrangements are common in other parts of the country (e.g. Dai, 2009). Such forms of relationship facilitate the engagement of HEIs into the localities on the one hand and help the HEIs' fundraising on the other.

Central government owned HEIs can also establish collaborative relationships with other provinces or cities outside their localities providing that they can offer attractive funding in return. Tsinghua University, for instance, signed collaborative contracts with 8 provinciallevel governments and 40 vice-provincial and prefectural level governments via their provincial governments, to jointly develop new campuses, science parks, and/or research 
institutes (Liu and Jiang, 2001). However, these activities are primarily motivated by profitseeking, in line with the move towards 'academic capitalism' noted above, and have involved intensive commercial-like negotiations between the university and local governments. In comparison to the engagement with the places where the HEIs are located, the collaborations with other places have generally been less productive (Wang, 2009).

At the local level, the collaborations between provincial-owned HEIs and prefectural-level governments resemble the pattern of the central-owned HEIs with provincial-level governments. Given the relative concentration of HEIs and other elements of production in the capital cities of provinces, the provincial capitals (who all enjoy prefectural or viceprovincial levels of administration) have advantages over other prefectural-level cities. Moreover, the establishment of official relationships between HEIs (either central-owned or provincial-owned) and county-level governments is unlikely because of their incomparable powers of administration.

\section{Forms of engagement}

This section will build on the analysis thus far by outlining some of the specific forms that regional engagement by HEIs in China takes. It will cover five types of engagement that are, in some broad comparable form, also present in many of the western countries covered in the academic literature: providing high-skilled workers to local labour markets, directly running business firms and enterprises, forming linkages with industry, collaborating in the establishment of science parks, and developing higher education campuses parks. These forms of engagement will be discussed in turn, with particular focus on the ways in which they are shaped by the higher education system reforms and governance framework described over the previous two sections, and on the regional development effects they have in relation 
to existing patterns of inequality between coastal and inland regions and between upper and lower-administrative level cities.

\subsection{Supplying high-skilled workers to labour markets}

As mentioned earlier, the entry of HEI graduates into local or regional labour markets took place only after the decentralisation of higher education in conjunction with the marketoriented economic reform. Instead of being allocated to jobs under the centrally-planned economy, higher education graduates were told to find employment opportunities from local, regional, and cross-regional labour markets (Williams et al., 1997). In the first few years this policy was welcomed by the non-state sectors because it meant that, for the first time, they could directly recruit the higher education graduates they needed. However, given that the Chinese economy is predominately driven by labour-intensive manufacturing and construction industries, the demand for highly educated workers has not kept up with the increase in graduates. The swift expansion of higher education has therefore resulted in graduates facing difficulties in finding suitable employment. As shown in Figure 2, the number of graduates remained fairly stable before 1999, but significant increases every year since 2003 has changed the landscape of the graduate labour market. When the first enlarged class of graduates entered the labour market in 2003, half of them could not find employment in the year, which represented a roughly equal proportion to that of the increased admission in 1999 (Chen, 2004), and in 2009 alone, about 2.0 million out of 6.11 million graduates remained unemployed (MOE, 2009). The high ratio of unemployment amongst higher education graduates has emerged as a major social concern, prompting the central government to force local authorities to generate more employment opportunities (People Daily, 2009). In such a context, local governments may come to see graduates more as a potential liability than as a future resource. 


\section{Insert Figure 2 here}

The unavailability of reliable nation-wide data means that a meaningful statistical analysis of inter-regional graduate flows is not possible. However, the large regional disparities in China means that there is an observable pattern that the relatively well-developed coastal regions can provide better opportunities and well-paid jobs for higher education graduates, not only from within those regions but also from the inland regions. This means that, while there will have been some concentration of graduates in the upper administrative level of cities, high quality graduates tend to be pulled into the cities in the coastal regions, in particular Beijing and Shanghai (Bai, 2006). The patterns of these main graduate flows from HEIs into employment are represented in the schematic diagram shown in figure 3 . In the context of the decentralisation of responsibility for higher education funding, this employment trend will arguably create a drain of talent as well as financial resources from lower level cities and/or inland lagging regions to the upper levels or core cities in coastal regions, which will inevitably further intensify regional inequality.

\section{Insert Figure 3 here}

The central government's policy aimed at promoting employment has had only moderate success. As one of the solutions to the high unemployment rate, the central government launched a scheme of recruiting more graduates as civil servants in 2006, which immediately made this the most competitive job opportunity amongst graduates in the country. Wang (2012) documents that, in 2011, there were 1.03 million graduates (out of a total of 6.08 million) competing for 16,000 office jobs at the central government. The ratio of candidates to jobs for some key posts has exceeded 3000 to 1 . This is also the case at provincial, prefectural, and county levels of government, particularly in lagging regions. With the household registration system (Hukou) still in effect, graduates who are unable to find jobs in 
cities where they studied in the year of graduation will have to move their Hukou back to their original places of registration. Given the lack of vibrant industries in the lagging localities and regions, the central government's policy that requires local governments to find employment for graduates has led to local governments recruiting more civil servants above the given quota. Considering the limited capacity of public finance in the lagging regions, the expansion of the government body will consume more public spending and, in turn, reduce investments in social and economic development.

Graduate entrepreneurship has also been promoted in the last few years, but with results that vary across localities and regions (Chen et al., 2010). The scheme asks local governments to support start-up firms established by graduates. In practice, this is often delivered through "start-up incubators" in conjunction with the development of the science or high and new technology industrial parks that will be discussed below. Nevertheless, this has once again fallen into the pattern associated with the regional disparities. In most cases, those graduates who return to their hometowns in poor regions simply do not have the required entrepreneurial ambitions or skills, and also face an unfavourable business environment for start-ups. Meanwhile, local governments also cannot compete with their counterparts in the rich localities and regions to offer attractive "start-up funds" (Jiang and Xu, 2012). The combination of these disadvantages means that poor localities and regions have faced greater barriers to benefiting from the increase in higher education graduates nationally.

\subsection{Running arms-length business firms and enterprises}

In the early stages of marketisation in China, most HEIs restricted themselves to running commissioned courses, offering adult education and evening courses. Some went beyond this by taking advantage of their higher education brand to open business firms and enterprises, joining in the nationwide proliferation of commercial activities (Mok and Wat, 1998). This 
was evidently successful in the short-term, and led to the flourishing of HEIs owned enterprises throughout China (Yang and Xu, 2004). By 1997, their number had reached its peak at 6634, generating RMB 29.6 billion sales income and RMB 2.72 billion profits (MOE, 1998). Most of these enterprises were involved in labour-intensive service activities, such as renting out their premises, running cafeterias or bars and off-campus hotels, and even turning their assembly halls into entertainment venues (Kwong, 1996). However, many of them failed to survive, leaving a great deal of debt and other problems to their parent HEIs (MOE, 2005).

Nevertheless, some exceptions exist, such as Tsinghua, Peking, and few other national renowned universities, which attempted to connect their research strengths with commercial business activities (Liu and Jiang, 2001). The relative success of these spin-off enterprises, together with the influence exerted by celebrated examples from Silicon Valley and elsewhere in the developed world, induced the government to establish a national scheme Integrating Teaching/Learning and Research with Production (ITLRP) - that encouraged HEIs to start businesses based on their knowledge and technology strengths (MOE et al., 1992). By 2010, more than 2200 HEI-run enterprises (60\% of the total) were high or new technology based businesses, generating over $80 \%$ of annual total sales income (Jiang, 2012). Some of these companies have been listed both in domestic and international stock markets.

From a local and regional development perspective, however, this policy has been highly controversial. As noted by $\mathrm{Wu} \mathrm{G}$ (2007), more than half of the total sales income was contributed by a small number of enterprises affiliated with a few top universities in Beijing, coinciding once again with the concentration of research universities and regional disparities. Given the policy of directing the majority of research funding into selected leading universities, the concentration of such universities in Beijing, Shanghai, and a few other 
provincial and vice-provincial level cities means that the benefits of knowledge spillovers from this mechanism of spin-out firms are mainly gained by these localities. The typically weaker research capability of HEIs located in lagging localities and regions, by contrast, means that they are unlikely to generate new technologies that could be used for immediate production, and their involvement in entrepreneurial activities has therefore rarely been linked to their research. Zhang (2003) and Yang and Xu (2004) also note that the policy of encouraging HEIs to be involved in entrepreneurial activities has risked the limited education funding of public funded HEIs in many inland regions by diverting resources into this entrepreneurial activity. Wu G (2007) observes that even in the core cities, the returns from many HEI-run enterprises have been relatively modest when compared with the investment needed.

\subsection{Linkages with industry}

The engagement of HEIs with industry involves both individual academic staff and institutional activities (Dai, 2009). Individuals may carry out commissioned research and consultancy, take secondary jobs in businesses relating to their expertise, work for enterprises whilst keeping only a nominal position in a HEI with no more responsibilities for teaching and research, or leave the HEI completely to work for enterprises or set up spin-off businesses (MOE et al., 1992). The enthusiasm with which this policy was met meant that a large number of academic staff engaged with industry whilst neglecting teaching and research (Wei, 1996). As a consequence, the engagement of individual academics with industry, whilst not banned, has subsequently been discouraged.

The institutional efforts of HEIs developing linkages with industry (other than directly running business firms and enterprises themselves) have by contrast received constant encouragement since its introduction. The collaboration, similar to in other countries, usually 
takes the form of knowledge and technology transfer through licensing and other arrangements such as consulting, joint or contract $R \& D$ and technical services, and joint ventures ( $\mathrm{Wu} \mathrm{W,} \mathrm{2007).} \mathrm{Nonetheless,} \mathrm{HEIs} \mathrm{adopt} \mathrm{different} \mathrm{strategies} \mathrm{and} \mathrm{attitudes} \mathrm{to}$ collaborate with different sized enterprises. Both central-owned and provincial-owned HEIs are keen to enter joint ventures with large companies, especially state-owned ones, to invest in and run laboratories and $\mathrm{R} \& \mathrm{D}$ centres, tailor-made training courses, and post-doctoral centres. In return, HEIs hope to create liaison networks with these large enterprises, enabling the effective circulation of $R \& D$ data and feedback of information on current demand levels from member enterprises. Given that the Chinese economy is dominated by labour-intensive manufacturing industry, the enthusiasm of the HEIs for these joint ventures has not been matched by demand from the enterprises. As a consequence, only a relatively few leading universities have the opportunity to pursue this form of engagement.

In contrast, public HEIs (particularly those that are central-owned) are usually unwilling to directly engage with small and medium sized enterprises (SMEs) apart from in fulfilling the tasks mandated respectively by central and provincial governments (Wang, 2009). HEIs therefore are requested to work with the Productivity Promotion Centres (PPC), a government's arms-length agency responsible for promoting science and technology and innovation, to exchange information between HEIs and SMEs (MOST, 1997; Wu G, 2007). Regardless of whether there is a match between the demand and supply, this pattern of collaboration will only work if the governments have enough authority to give orders to the HEIs. Given that the HEIs with research capabilities normally have prefectural-level power of administration or above, this has developed into a situation where prefectural and county levels of government, which are directly responsible for their local SMEs, have no authority to ask such HEIs to cooperate with the PPCs in their area. Once again, only those SMEs located in the vice-provincial or provincial-level cities may have benefited from this policy. 
On the other hand, even when HEIs are willing to provide such consultancy services directly to local SMEs, in most cases the cost is unaffordable to many SMEs.

\subsection{Science Parks}

Drawing on success stories from both international and national practice, such as Stanford University Science Park, Cambridge Science Park, and Zhongguancun High Technology Park, in 2000 the Ministry of Science and Technology and the Ministry of Education (MOST and MOE, 2000) jointly announced a national programme - National University Science Park (NUSP) - encouraging HEIs specialising in science, technology, and engineering disciplines to establish science parks. As part of this programme, policy incentives such as tax breaks, low interest loans, and free use of land are made available both by central and provincial levels of government (MOST, 2000). A science park that meets a set of criteria will qualify for $\mathrm{NUSP}^{6}$ status and therefore enjoy more support from the central government (MOST and MOE, 2004). In practice, given the public finance arrangements in China, both HEIs and local governments see the NUSP programme as an opportunity for commercial benefits, and therefore, competition between places to have a NUSP is high. By 2012, 98 science parks, with the involvement of 134 HEIs, had qualified as NUSP, of which 14 are located in Beijing and 13 in Shanghai (MOST and MOE, 2013).

Detailed information on the performance of the NUSPs is not available and there is no academic study attempting to evaluate the programme as a whole, but a news report by Zhao (2009) notes that with the exception of a few that involve national leading research universities, most NUSPs have faced problems either in terms of lacking research strengths in technology and engineering or encountering operational difficulties ${ }^{7}$. Given the geographic concentration of universities with research capabilities, a few core cities have again particularly benefited from this programme. In many other cases, the programme has been 
treated as a political assignment and an opportunity to compulsorily convert more agricultural land to urban development use from which profits may be made due to the increased land value (Wang, 2009).

\subsection{Higher education campus parks}

The development of higher education campus parks (HECP), also commonly referred to as "university towns" in China, was initially a reactive response to the radical expansion of higher education admission beginning in 1999 (Dong, 2005). In order to accommodate the significantly increased number of students, HEIs were prompted to expand their campuses or build entirely new campuses using bank loans at subsidised interest rates. The potential contributions of these projects to urban development processes were however also soon recognised. In order to maximise these economic benefits, several HEIs were often directed to co-locate in one designated area which is usually in suburban areas that were relatively detached from the city core (Shu, 2003). There are more than 50 designated HECPs, with land areas ranging from 20 to $70 \mathrm{~km}^{2}$ (Wei, 2006). Some large HECPs are able to accommodate over 600,000 students, and the land area for each campus is normally over five times larger than the old ones (Shu, 2003).

As with the building of new higher education campuses or buildings internationally (Perry and Wiewel, 2008), the development of HECPs in China may have positive impacts on local economic growth, but also potential drawbacks. They have been criticised for having been "only meaningful for local GDP growth in the short run" (Chen and Zhang, 2004), while encumbering HEIs with debts of at least RMB 450 billion by 2011 (Cao, 2012). In some lagging regions, the huge debts have left HEIs struggling to survive. As a result many HEIs unlawfully charge students with extra fees on the top of tuition fees, while others venture into the real estate development business by taking advantage of the low priced land they acquired 
for campuses (Wei, 2006). This has not only caused tensions between students and the HEIs, but also potentially put the public finances of the responsible local governments, particularly those in lagging regions, at risk (Liu, 2012).

\section{Conclusion}

This paper has presented a preliminary analysis of the different forms and effects of regional engagement by HEIs in China. The intention has not been to cover these different forms of engagement in a highly detailed or comprehensive way ${ }^{8}$, but to outline a broad framework of understanding that can help guide future research. In particular, we have aimed to highlight connections and parallels with the international literature on higher education and regional engagement, whilst also reflecting the specificity of the institutional context for this relationship in China.

The paper has described the historical trajectory through which decentralisation policies since the mid 1980s have enabled the Chinese higher education system to evolve from being entirely focused on national development objectives to also encouraging direct links with local and regional development. These reforms can be interpreted as sharing some elements in common with global trends towards expansion, marketisation, and regional decentralisation in higher education systems that, as the western-focused literature reviewed earlier explains, has facilitated and shaped the often uneven regional development impacts of HEIs in other national settings. The paper has, however, also emphasised that different forms of regional engagement and their territorial development effects in China, including those related to the entry of graduates into labour markets, university enterprises and links with industry, and science park or campus development projects, take distinctive forms that stem in part from the particular governance system in which HEIs are based. 
The paper has also related these forms of regional HEI engagement to patterns of uneven territorial development in China. Specifically, we have shown that cities enjoying higher levels of administration in general, and core cities with concentrations of national leading universities owned by the central government in particular, have been the major beneficiaries of the national policy encouraging HEIs to engage in local and regional development. A conclusion therefore can be drawn that this policy has generally served to enhance patterns of regional inequality between the coastal and inland regions and between upper and loweradministrative level cities. This is argued to be a product of certain structural and institutional factors, such as the politicisation of higher education, the incorporation of HEIs into the administrative hierarchy, and the disequilibrium of funding schemes between central and provincial owned HEIs. If higher education is to be utilised to help reduce regional disparities in China, therefore, this suggests that HEIs will have to be de-coupled from the political and administrative hierarchy, as well as appropriate reforms of the funding schemes carried out to help HEIs in lagging localities and regions that are developing towards becoming more research-intensive universities. Such reforms will need to be coordinated with measures to help retain and attract high quality graduates to lagging localities and regions through fostering vibrant industries driven by knowledge or technology innovation and reducing dependency on employment in the public sector. 


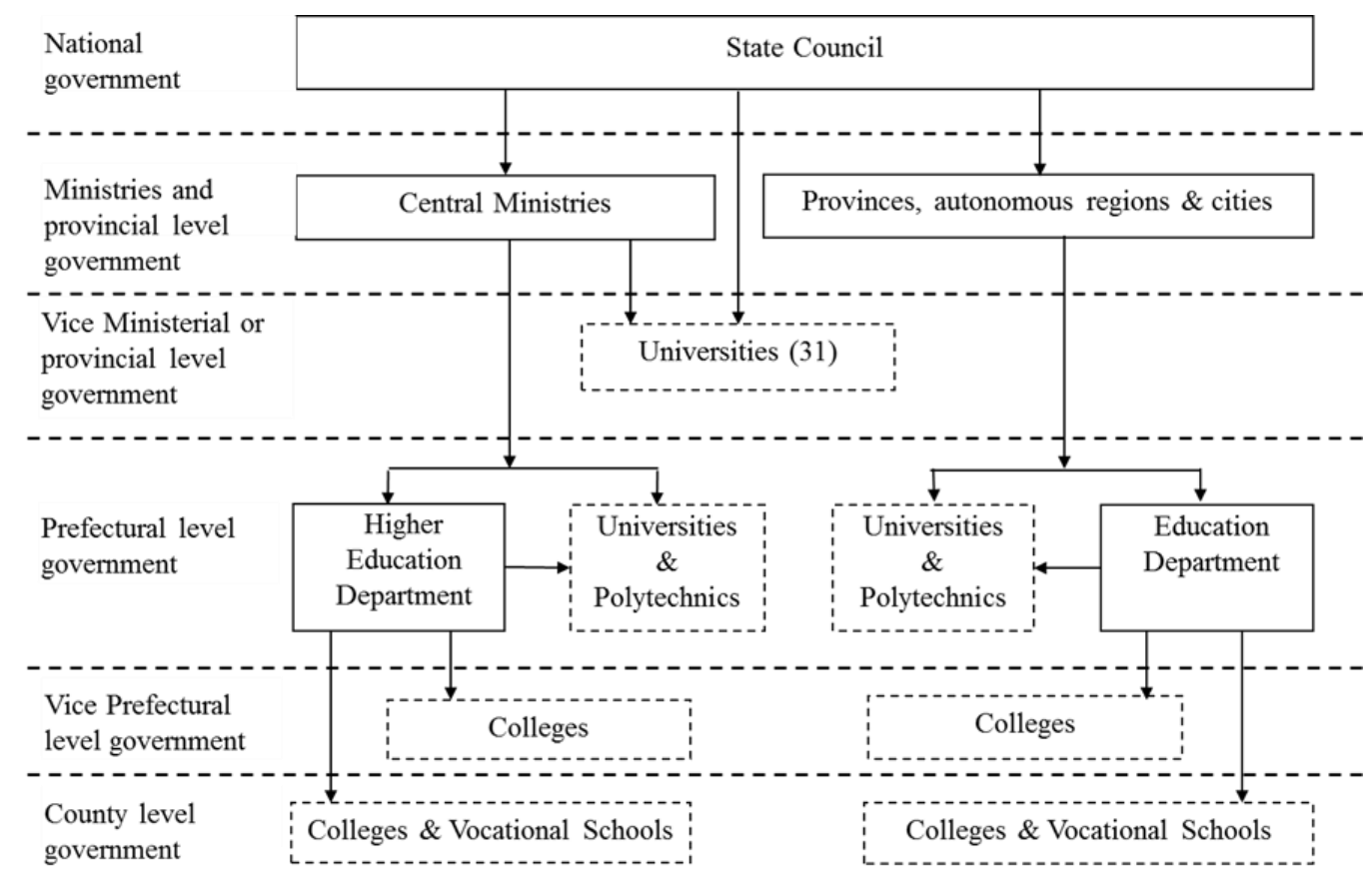

Figure 1. Accountability and administrative hierarchy of China's HEI

Source: Author's research 
Table 1. Number of HEIs by province and accountability

\begin{tabular}{|c|c|c|c|c|c|c|}
\hline & $\begin{array}{l}\text { HEIs in } \\
\text { total }\end{array}$ & Universities & Colleges & $\begin{array}{l}\text { Central } \\
\text { Owned }\end{array}$ & $\begin{array}{l}211 \\
\text { Universities }\end{array}$ & $\begin{array}{l}985 \\
\text { Universities }\end{array}$ \\
\hline National total & 2138 & 841 & 1297 & 110 & 112 & 39 \\
\hline Beijing & 83 & 57 & 26 & 34 & 26 & 9 \\
\hline Shanghai & 63 & 31 & 32 & 10 & 9 & 4 \\
\hline Jiangsu & 128 & 46 & 82 & 10 & 11 & 2 \\
\hline Hebei & 95 & 37 & 58 & 4 & 1 & 0 \\
\hline Tianjin & 45 & 19 & 26 & 3 & 3 & 2 \\
\hline Guangdong & 120 & 40 & 80 & 3 & 4 & 2 \\
\hline Shandong & 124 & 49 & 75 & 2 & 3 & 2 \\
\hline Fujian & 77 & 23 & 54 & 2 & 2 & 1 \\
\hline Zhejiang & 80 & 33 & 47 & 1 & 1 & 1 \\
\hline Hainan & 17 & 6 & 11 & 0 & 1 & 0 \\
\hline East subtotal & 832 & 341 & 491 & 69 & 61 & 23 \\
\hline Shannxi & 79 & 42 & 37 & 6 & 7 & 3 \\
\hline Sichuan & 86 & 34 & 52 & 6 & 5 & 2 \\
\hline Gansu & 37 & 15 & 22 & 2 & 1 & 1 \\
\hline Chongqing & 53 & 17 & 36 & 2 & 2 & 1 \\
\hline Ningxia & 14 & 6 & 8 & 1 & 1 & 0 \\
\hline Tibet & 6 & 3 & 3 & 0 & 1 & 0 \\
\hline Qinghai & 8 & 3 & 5 & 0 & 1 & 0 \\
\hline Inner Mongolia & 46 & 13 & 33 & 0 & 1 & 0 \\
\hline Xinjiang & 34 & 13 & 21 & 0 & 2 & 0 \\
\hline Yunnan & 59 & 22 & 37 & 0 & 1 & 0 \\
\hline Guizhou & 41 & 17 & 24 & 0 & 1 & 0 \\
\hline Guangxi & 61 & 22 & 39 & 0 & 1 & 0 \\
\hline West subtotal & 520 & 207 & 313 & 17 & 24 & 7 \\
\hline Hubei & 96 & 40 & 56 & 8 & 7 & 2 \\
\hline Hunan & 106 & 31 & 75 & 3 & 3 & 2 \\
\hline Anhui & 107 & 33 & 74 & 2 & 3 & 1 \\
\hline Henan & 112 & 39 & 73 & 1 & 1 & 0 \\
\hline Shanxi & 67 & 19 & 48 & 0 & 1 & 0 \\
\hline Jiangxi & 75 & 24 & 51 & 0 & 1 & 0 \\
\hline Centre subtotal & 563 & 186 & 377 & 14 & 16 & 5 \\
\hline Liaoning & 94 & 45 & 49 & 5 & 4 & 2 \\
\hline Heilongjiang & 77 & 34 & 43 & 3 & 4 & 1 \\
\hline Jilin & 48 & 28 & 20 & 2 & 3 & 1 \\
\hline Northeast subtotal & 219 & 107 & 112 & 10 & 11 & 4 \\
\hline
\end{tabular}

Source: Adapted from MOE (2012) 


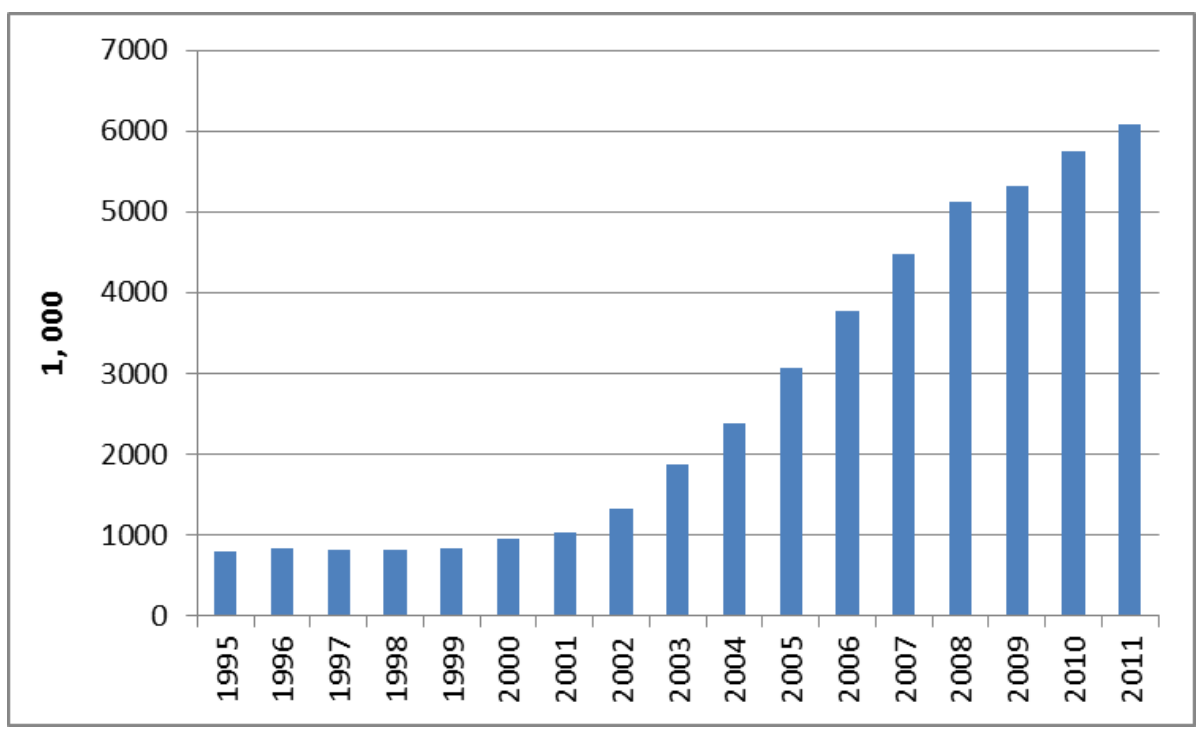

Figure 2. Number of graduates (1995-2011)

Source: NBSC, 2012 


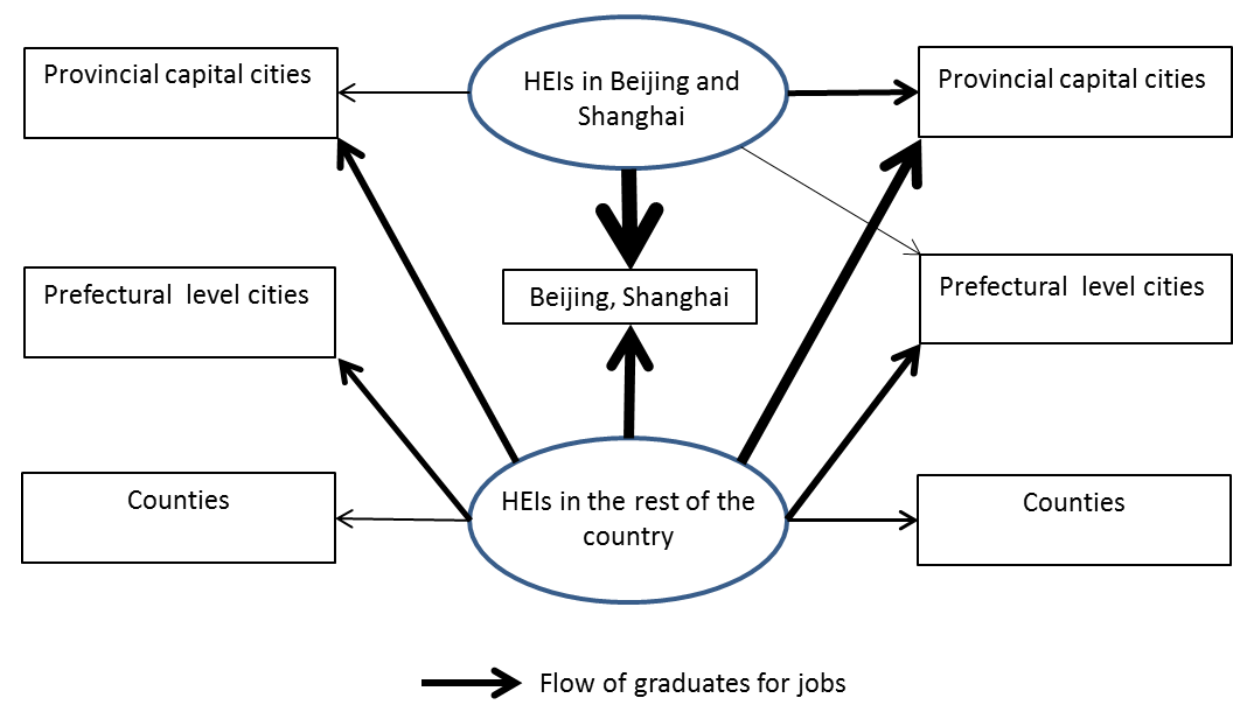

Weights of the arrows represent the size of flows

Figure 3. The illustration of flows of graduates for employment

Source: Authors' research. 


\section{References}

Andersson R, Quigley J M, Wilhelmson M, 2004, "University decentralization as regional policy: the Swedish experiment" Journal of Economic Geography 4 371-388

Bai, L, 2006, "Graduate Unemployment: Dilemmas and Challenges in China's Move to Mass Higher Education” The China Quarterly 185 128-144

Benneworth P, Herbst M, 2014, "The city as a focus for human capital migration: towards a dynamic analysis of university human capital contributions" European Planning Studies 23 452-474.

Boucher G, Conway C, Van Der Meer E, 2003, "Tiers of engagement by universities in their region's development" Regional Studies 37 887-897

Breschi S, Lissoni F, 2001, "Knowledge spillovers and local innovation systems: a critical survey" Industrial and Corporate Change 10 975-1005.

Cai K, 2006 China's higher education in the 20th century (China Higher Education Press Beijing)

Cameron D M, 1992, "Higher education in seven federal systems: a synthesis", in Higher Education in Federal Systems Eds D, Brown, P, Cazalis, J, Gilles (Institute of Intergovernmental Relations: Kingston) pp 29-43

Cao S, 2012, "A study on the debt issue of regular institutes of higher education in China (in Chinese)" China Higher Education Studies 27 63-67

Chen A, Wu B, 2012, "The regional division of the higher education sector in China", in Higher Education Reform in China Eds W J, Morgan, B, Wu (Routledge Oxom) pp 13 $-31$

Chen F, Zhang H, 2004, "Beyond the hype of university town” China Education 35 6-8

Chen W, Wang B, Shi Q, 2010, "Creating the mechinism for higher education graduates entrepreneurship led employment (in Chinese)" Higher Agricultural Education 5 69-72

Chen X, 2004, "Making efforts to solve problems of employment for graduates in regular universities", in The Work Meeting of Higher Education Graduates Employment (Ministry of Education Beijing)

Cheng K, 1998, "Reforms in the administration and financing of higher education", in Higher Education Reform in Post-Mao China Eds M Agelasto, B Adamson (Hong Kong University Press Hong Kong ) pp 11-27

Clark B R, 1998, "The entrepreneurial university: demand and response" Tertiary Education and Management 4 5-16 
Coe N M, Hess M, Yeung H W, Dicken P, Henderson J, 2004, “'Globalizing'regional development: a global production networks perspective" Transactions of the Institute of British Geographers 29 468-484

Cooke T J, Boyle P, 2011, "The migration of high school graduates to college" Educational Evaluation and Policy Analysis 33 202-213.

Crespy C, Heraud J-A, Perry B, 2007, "Multi-level governance, regions and science in France: between competition and equality" Regional Studies 41 1069-1084

Dai Z, 2009, "Nanjing university and the development of Jiangsu province", in Public Universities and Regional Development Eds K Mohrman, J Shi, S Feinblatt, K W Chow (Sichuan University Press Chengdu ) pp 191-204

Danson M, Lloyd G, 2012, "Devolution, institutions and organisations: changing models of regional development agencies" Environment and Planning C: Government and Policy 30 78-94.

Delanty G, 2002, "The university and modernity: a history of the present", in The Virtual University: Knowledge, Markets, and Management Eds Robins K, Webster F (Oxford University Press: Oxford) pp 31-48

Dill D D, 1997, "Higher education markets and public policy" Higher Education Policy 10 167-185

Ding L, 2007, “Advantages and disadvantages of universities and colleges' mergence and measures for adjustment" Exploration and Free Views 23 71-73

Ding Y, Hu J, 2012, “An emperical study of local economy and disparity of local higher education funding (in Chinese)" Education and Economy 28 38-43

Dong Y, 2005, "Current state, problems and future trend of university towns in China (in Chinese)" Journal of Zhejiang Education Institute 6 89-95

Dunford M, 2011, "Area definition and classification and regional development finance: the European Union and China", in Handbook of Local and Regional Development Eds A Pike, A Rodrguez-Pose, J Tomaney (Routledge Oxon) pp 527-547

Ernst D, Kim L, 2002, "Global production networks, knowledge diffusion, and local capability formation" Research Policy 31 1417-1429

Etzkowitz H, 2012, "Triple helix clusters: boundary permeability at university-industrygovernment interfaces as a regional innovation strategy" Environment and Planning C: Government and Policy 30 766-779

Fan C C, 1997, "Uneven development and beyond: regional development theory in post-Mao China" International Journal of Urban and Regional Research 21 620-639

Fan C C, Sun M, 2008, "Regional inequality in China, 1978-2006" Eurasian Geography and Economics 49 1-18 
Fujita M, Hu D, 2001, "Regional disparity in China 1985-1994: the effects of globalization and economic liberalization" The Annals of Regional Science 35 3-37

Goddard J, Chatterton P, 1999 "Regional Development Agencies and the knowledge economy: harnessing the potential of universities" Environment and Planning C: Government and Policy 17 685-699

Goddard J, Vallance P, 2013, The University and the City (Routledge, London)

Groen J A, White M J, 2004, "In-state versus out-of-state students: the divergence of interest between public universities and state governments" Journal of Public Economics $\mathbf{8 8}$ 1793-1814

Henderson J, Dicken P, Hess M, Coe N, Yeung H W C, 2001, "Global production networks and the analysis of economic development" Review of international political economy 9 $436-464$

Hoare A, Corver M, 2010, "The regional geography of new young graduate labour in the UK" Regional Studies $\mathbf{4 4}$ 477-494

Huggins R, Johnston, A, 2009, "The economic and innovation contribution of universities: a regional perspective" Environment and Planning C: Government and Policy 27 10881106

Jiang T, 2012, "A thought of the problems of enterprises run by higher education institutions" Henan Education 8 26-27

Jiang X, Xu W, 2012, "A study on the problems of higher education graduates entrepreneurship" Economic Observation 22 24-26

Jones M, 2001, "The rise of the regional state in economic governance: "partnerships for prosperity' or new scales of state power?’Environment and Planning A 33 1185-1211

Keating M, 1997, "The invention of regions: political restructuring and territorial government in Western Europe" Environment and Planning C: Government and Policy 15 383-398.

Keating M, 2005, "Higher education in Scotland and England after devolution" Regional and Federal Studies 15 423-435

Kitagawa F, 2005, "Regionalization of innovation policies: the case of Japan" European Planning Studies 13 601-618

Kodrzycki Y K, 2001, "Migration of recent college graduates: evidence from the national longitudinal survey of youth" New England Economic Review January-February 1334

Kwong J, 1996, "The new educational mandate in China: running schools running businesses" International Journal of Educational Development 16 185-194

Labrianidis L, 2010, "The Greek university stranded in the policy of establishing regional universities" European Planning Studies 18 2009-2026. 
Lawton Smith H, 2007, "Universities, innovation, and territorial development: a review of the evidence" Environment and Planning C: Government and Policy 25 98-114

Li H, Zhao C, 2009, "Contributions to development through support and integration", in Public University and Regional Development Eds K Mohrman, J Shi, S Feinblatt, K W Chow (Sichuan University Press Chengdu) pp 81-93

Li J, Chen P, Huang H, 2003, “A study of China's higher education reform" Journal of Shanghai Jiaotong University 11 17-22

Li Y, Wu F, 2012, "The transformation of regional governance in China: The rescaling of statehood" Progress in Planning 78 55-99

Liu H, Jiang Y, 2001, “Technology transfer from higher education institutions to industry in China: nature and implications" Technovation 21 175-188

Liu M, 2012, "Debts in local higher education institutions: current state, problems and solutions" Journal of Inner Mongolia University of Technology 21 37-39

Liu N, 2007, "Research universities in China: differentiation, classfication, and future worldclass status", in Transforming Research Universities in Asia and Latin America: World Class Worldwide Eds G A Philip, J Balan (The Johns Hopkins University Press Baltimore, Maryland ) pp 54-69

Lu D, Yao S, Liu H, Gao X, Li G, Duan J, 2007, China Regional Development 2006 (in Chinese) (The Commercial Press, Beijing)

Lundvall B, Borrás S, 2005, "Science, technology, and innovation policy", in The Oxford Handbook of Innovation Eds J, Fagerberg, D C, Mowery, R R, Nelson (Oxford University Press, Oxford) pp 599-631

Ma W, 2004, From Berkeley to Peking and Tsinghua: The development and governance of public research universities in the US and China (in Chinese) (Educational Science Press, Beijing)

Man J Y, 2011, "Local public finance in China: an overview", in China's Local Public Finance in Transition Eds J Y Man, Y Hong (The Lincoln Institute of Land Policy Cambridge, MA ) pp 3-20

Marginson S, 2006, "Dynamics of national and global competition in higher education" Higher Education 52 1-39

Martinez-Vazquez G, Qiao B, 2011, “Assessing the assignment of expenditure responsibilities”, in China's Local Public Finance in Transition Eds J Y Man, Y Hong (Lincoln Institute of Land Policy Cambridge, MA ) pp 21-40

Min W, 2004, "Chinese higher education: the legacy of the past and the context of the future", in Asian Universities: Historical perspectives and contemporary challenges Eds P G Altbach, T Umakoshi (The Johns Hopkins University Press Baltimore, Maryland ) pp 53-84 
MOE, 1993a, Provisional Regulations for the Establishment of Private Higher Education, (Ministry of Education, Beijing )

MOE, 1993b, Some Suggestions for Further Promoting Number of Premium Higher Education Institutions and Key Desciplines (Ministry of Education, Beijing)

MOE, 1998, "Annual Report on Statistics of Enterprises Run by Higher Education Institutions (1997)", Ministry of Education, Beijing

MOE, 2005, "Annual Report on Statistics of Enterprises Run by Higher Education Institutions (2004)", Ministry of Education, Beijing

MOE, 2006, “The Report of Progression of '211' and '985' Programs” Ministry of Education, Beijing

MOE, 2009, "Statistic Information of Higher Education Graduates Employment", Ministry of Education, Beijing

MOE, 2012, "The list of higher education institutions approved by the ministry of education (in Chinese)", http://www.moe.gov.cn/publicfiles/business/htmlfiles/moe/moe_229/201205/135137.ht $\mathrm{ml}$

MOE, CAS, SCET, 1992, The decision for launching the national programme of integrating higher learning/teaching and researching with producing (chan xue yan yi ti hua) (in Chinese), (State Commission of Education, Chinese Academy of Science, State Commission of Economy and Trade, Beijing)

Mok K-H, Wat K-Y, 1998, "Merging of the public and private boundary: education and the market place in China" International Journal of Educational Development 18 255-267

Mok K H, 2000, "Marketizing higher education in post-Mao China" International Journal of Educational Development 20 109-126

MOST, 1997, Regulations on Productivity Promotion Centre (The Ministry of Science and Technology, Beijing )

MOST, 2000, Regulations on National University Science and Technology Park (in Chinese) (Ministry of Science and Technology of China, Beijing)

MOST, 2012, "Statistical Report on National University Science Parks", The Ministry of Science and Technology of China, Beijing

MOST, MOE, 2000, National Plan of University Science Park (in Chinese), (Ministry of Science and Technology of China; Ministry of Education of China, Beijing)

MOST, MOE, 2004, The Decision on Further Prioritising the Development of National University Science Park (Ministry of Science and Technology of China and Ministry of Education of China, Beijing ) 
MOST, MOE, 2006, Outlining the National University Science Parks for the Eleventh FiveYear Plan (Ministry of Science and Technology of China and Ministry of Education of China, Beijing )

MOST, MOE, 2013, The Ninth Informing on the Qualification of National University Science Parks (The Ministry of Science and Technology of China and the Ministry of Education of China, Bejing)

NBSC, 2008, “Statistic Yearbook 2007”, National Bureau of Statistics of China, Beijing

NBSC, 2012, "Statistic Yearbook 2011”, National Bureau of Statistics of China, Beijing

OECD, 2007, Higher Education and Regions: Globally Competitive, Locally Engaged (OECD, Paris)

Paterson L, 2001, "Higher education and European regionalism" Pedagogy, Culture and Society 9 133-160

Patton D, Kenney M, 2010, "The role of the university in the genesis and evolution of research-based clusters", in Emerging Clusters: Theoretical, Empirical, and Political Perspectives on Initial Stage of Cluster Evolution Eds D, Fornahl, S, Henn, M-P, Menzel (Edward Elgar Publishing Limited, Cheltenham) pp 214-238

People Daily, 2009, "State Council Working Conference: Do Best to Provide Employment Opportunities for Higher Education Graduates" People Daily 08 January page 01

Perry B, May T, 2007, “Governance, science policy and regions: an introduction” Regional Studies 41 1039-1050

Perry D C, Wiewel W, 2008, "The university, the city, and land: context and introduction", in Global Universities and Urban Development: Case Studies and Analysis Eds W, Wiewel, D C, Perry (M. E. Sharpe, London) pp 3-24

Ren, E., Wang, A., Li, Z., Cheng, J., Zhang, L. and Sun, S. (2007) A Study of Theoretical and Practical Issues of the Development of University Science Parks in the Western Region (in Chinese) (Lanzhou Jiaotong University, Lanzhou)

Rodríguez-Pose A, Gill N, 2003, "The global trend towards devolution and its implications" Environment and Planning C: Government and Policy 21 333-351.

Rodríguez-Pose A, Sandall R, 2008, "From identity to the economy: analysing the evolution of the decentralisation discourse" Environment and Planning C: Government and Policy 26 54-72.

Saarivirta T, 2010, "Finish higher education expansion and regional policy" Higher Education Quarterly 64 353-372.

Schiller D, 2006, "Nascent innovation systems in developing countries: university responses to regional needs in Thailand" Industry and Innovation 13 481-504.

Schofer E, Meyer J W, 2005, "The worldwide expansion of higher education in the twentieth century" American Sociological Review 70 898-920 
Shao X, Wang G, 2010, "A study of the reform of public spending on higher education in China (in Chinese)" 21 Economic Reform 127-131

Shen B, 2004, "China's regional disparity in 1981-2000: openness and development of nonstate-owned enterprises and fiscal decentralization" Chinese Geographical Science $\mathbf{1 4}$ 97-103

Shu J, 2003, "Rethinking of the development of university towns" Journal of Estern China University 16 3-6

Slaughter S, Leslie L L, 1997, Academic Capitalism: Politics, Policies, and the Entrepreneurial University (The John Hopkins University Press, Baltimore)

Slaughter S, Leslie L L, 2001, "Expanding and elaborating the concept of academic capitalism" Organization 8 154-161

Smith R H T, Wood F, 1992, "Higher education in federal systems: Australia", in Higher Education in Federal Systems Eds D, Brown, P, Cazalis, J, Gilles (Institute of Intergovernmental Relations: Kingston) pp 95-123

Sohn D-W, Kim H, Lee J H, 2009, "Policy-driven university-industry linkages and regional innovation networks in Korea" Environment and Planning C: Government and Policy 27 647-664

Teixeira P, Rocha V, Biscaia R, Cardoso M F, 2014, "Policy changes, marketisation trends and spatial dispersion in European higher education: comparing public and private sectors" Cambridge Journal of Regions, Economy and Society 7 271-288.

Tomaney J, Wray F, 2011, "The university and the region: an Australian perspective" International Journal of Urban and Regional Research 35 913-931

Trow M, 1992, "Origins and development of federalism in American higher education", in Higher Education in Federal Systems Eds D, Brown P, Cazalis J, Gilles (Institute of Intergovernmental Relations: Kingston) pp 69-94

Uyarra E, 2010, "Conceptualizing the regional roles of universities, implications and contradictions" European Planning Studies 18 1227-1246

van Winden W, de Carvalho L, van Haaren J, van den Berg L, (2012) Creating Knowledge Locations in Cities (Routledge, Abingdon)

Venhorst V A, 2013, "Graduate migration and regional familiarity" Tijdschriftvoor Economische en Sociale Geografic 104 109-119

Wang B, 2010, "A study of the socio-cultural factors of politicalisation of higher education in China (in Chinese)" Education Exploration 232 56-58

Wang X, 2009, Knowledge-based Urban Development in China, PhD Thesis, Centre for Urban and Regional Development Studies, University of Newcastle, Newcastle upon Tyne 
Wang Y, 2012, "An analysis of higher education graduates taking the examination for recruiting civil servants (in Chinese)" Journal of Human Resources Development 26 $21-22$

Wei F, 1996, "The great tremors in China's intellectuals circles: an overview of intellectuals floundering in the sea of commercialism (in Chinese)". Chinese Education and Society 29 7-14.

Wei W, 2006, "Some universities are going to be bankrupted (in Chinese)" People' Daily 26 June, page 05

Wei Y, Zhang G, 1995, “A historical perspective on nongovernmental higher education in China", paper presented at the International Conference of Private Higher Education in Asia and the Pacific Region (The University of Xiamen, Xiamen)

Williams G, Liu S S, Qiuheng S, 1997, "Marketization of higher education in the People's Republic of China" Higher Education Policy 10 151-157

Wu G, 2007, "The role of HEIs in the development of national innovation system" China Higher Education 43 11-14

Wu W, 2007, "Cultivating Research Universities and Industrial Linkages in China: The Case of Shanghai" World Development 35 1075-1093

Yang D, 2010, "Theoretical thoughts on the governance of the defects of administrative education (in Chinese)" Education Development Studies 19 50-55

Yang J, Xu X, 2004 The Theory and Practice of University Enterprise Security (in Chinese) (China Economics Press, Beijing )

Zhang C, 2009, "The eight colleges and the construction of higher education framework in people's republic of China" China Education Daily 31 August, page 03

Zhang J, 2003, The Development of High-Tech Enterprises in China's Universities (Huazhong Science and Technology University Press, Wuhan)

Zhang X, Zhang K H, 2003, "How does globalisation affect regional inequality within a developing country? Evidence from China" Journal of Development Studies 39 47-67

Zhao X, 2009, "the future of national university science park: the national university science park program 10 years on" China Education Daily 17 Novemebr, page 03

Zhou Y, 2006, Foreword for China's Higher Education in the 20th Century (China Higher Education Press, Beijing) 
${ }^{1}$ For instance, this founding of new universities in peripheral regions has been used as an explicit regional policy tool in countries including Sweden, Greece, and Finland (Andersson et al. 2004; Labrianidis, 2010; Saarivirta, 2010).

2 These arrangements are also subject to change over time: for instance in Australia during the 1970s the federal government assumed full control for the funding of higher education (and therefore also greater control over planning and coordination of the sector) due to its stronger financial position relative to the state governments (Smith and Wood, 1992; Tomaney and Wray, 2011).

${ }^{3}$ Under the centrally-planned economy, central government owned enterprises/research institutions were part of central ministries. They were not allowed to recruit staff locally, who were instead allocated by the responsible central ministry. The profits made by the enterprises were taken directly by the central government. The only link between them and the localities was food supply which put a heavy burden on local governments in the time when there was a general food shortage. Local governments therefore tended to oppose the location of HEIs and central government owned enterprises/research institutions in their places.

${ }^{4}$ There is a terminology issue here. Given the multilevel government system in China, the term "region" may indicate different spatial scales in different contexts. In the Chinese convention, the lower levels of administrative territories are usually referred to as "local" by the upper levels. Hence, this process is more likely to be referred to as 'localisation' in Chinese, but this decentralisation of HEIs to provincial level governments is actually closer in western terms to a policy of regionalisation.

${ }^{5}$ The transfer of ownership of HEIs to provincial level governments did not change the political and administrative levels of the HEIs that had been designated.

${ }^{6}$ A typical NUSP usually occupies at least 150 ha of land (usually located within the High and New Technology Industrial Zones), and is comprised of a number of business incubators - including graduate start-up incubators, foreign-educated returnees start-up incubators, and university spin-off incubators; R\&D facilities - including open laboratories; factories; and service facilities - such as venture capital and investment, marketing and management consultancies, and property management (MOST and MOE, 2006). In 2012 there were 6617 start-ups currently in the incubators, and more than 4300 firms previously based in the incubators that had moved out (MOST, 2012).

${ }^{7}$ This picture is supported by a case study conducted in Lanzhou (Ren et al., 2007). 
${ }^{8}$ Indeed, other notable forms of engagement have emerged more recently, such as sending academic and administrative staff to peripheral local governments to help policy-making and recruiting higher education graduates to work as assistant head of village communities, which have not been discussed in this paper due to the limited data on them that is currently available. 